\title{
38. CARBONATE AND COARSE FRACTION RECORDS OF THE PLEISTOCENE INTERVAL IN THE NORTH ATLANTIC, HYDRAULIC PISTON CORER HOLE 558A ${ }^{1}$
}

\author{
Gordon G. Start, Department of Geological Sciences, Brown University²
}

\begin{abstract}
Carbonate and coarse fraction data from Hole 558A record variations in the carbonate system for the Pleistocene. The late Pleistocene carbonate record from Hole 558A can be correlated to Atlantic carbonate records with similar accumulation rates. The correlation between carbonate and coarse fraction record in Hole 558A does not remain constant. The early Pleistocene carbonate-coarse fraction correlation is opposite of the typical North Atlantic pattern, whereas late Pleistocene carbonate-coarse fraction correlation does not show consistent pattern. The different relationships between the carbonate and coarse fraction records suggests that the carbonate system in the North Atlantic changed between the early and late Pleistocene.
\end{abstract}

\section{INTRODUCTION}

Information about local and global ocean climate is provided by a variety of indexes from deep-sea sediments, such as oxygen isotopic values from foraminiferal tests (Emiliani, 1955); sediment composition (Arrhenius, 1952); and faunal abundances (Phleger et al., 1953). In late Pleistocene deep-sea sediments, the carbonate record has long been recognized as a monitor climatic change (Arrhenius, 1952; Ruddiman, 1971; Volat et al., 1980). However, the exact relationship between climate and carbonate systems varies between ocean basins (Volat et al., 1980). In late Pleistocene Atlantic sediments, low carbonate values correspond with glacial intervals and high carbonate values with interglacial intervals. This covariance is termed the "Atlantic-type" pattern. The Atlantic pattern also has high coarse fraction values during interglacials and low coarse fraction values during glacials (Broecker, 1971; Prell, 1978).

The oxygen isotope composition of foraminifers has been established as a measure of the climatic system to which other indexes are compared. The isotopic variations reflect changes in the amount of continental ice volume (Shackleton, 1967). In this paper, the oxygen isotope curve will be used as the measure of the variations in the climatic system.

Prell (1982) described two modes of variability in the $\delta^{18} \mathrm{O}$ record for the Pleistocene. These two modes of variability span about equal periods of time and provide a simple division of the Pleistocene into two units: a late Pleistocene ( 0 to $0.8 \mathrm{Ma}$ ) and an early Pleistocene ( $0.8 \mathrm{Ma}$ to the Pliocene/Pleistocene boundary). These informal units can be applied to the isotopic and other records of climatic variability.

Carbonate variations are not directly dependent on climate variations, but are linked to the climate system through a complex function of a large number of vari-

\footnotetext{
${ }^{1}$ Bougault, H., Cande, S. C., et al., Init. Repts. DSDP, 82: Washington (U.S. Govt. Printing Office).

2 Address: Department of Geological Sciences, Brown University, Providence, Rhode Island 02912-1846.
}

ables (Berger, 1976; Volat et al., 1980; Broecker and Peng, 1982). The majority of carbonate variance can, however, be expressed as a function of three primary factors: productivity, dissolution, and dilution. Upper Pleistocene North Atlantic carbonate values have been shown to be directly related to the noncarbonate (mostly terrigenous) component of the sediment (Ruddiman and McIntyre, 1976). Dissolution decreases the carbonate content and increases the fragmentation of foraminiferal tests resulting in lower coarse fraction values. Productivity affects the carbonate system by changing the input of carbonate material; however, increased productivity also increases dissolution of carbonate by increasing the amount of $\mathrm{CO}_{2}$ in the water column.

Previous studies of long climate records have shown that the climatic system has different modes of variability (Shackleton and Opdyke, 1976; Berger, 1982; Prell, 1982). Other indexes dependent on climatic variations, including the carbonate system, should reflect these changes in variability, but the sense and the magnitude of the changes between modes are dependent on the links between climate and the recording index. These links between climate and the recording index may also change with time. Examination of long carbonate records should provide insights into the nature of the interrelationships between the climatic and carbonate systems and how they change.

Detailed carbonate records for the early Pleistocene are rare; most lack the resolution needed to define variations on the same scale as observed climatic variations. Hole 558A provides a record of the carbonate variations for the North Atlantic spanning the entire Pleistocene. Carbonate and coarse fraction curves for Hole 558A are presented in this report and compared to other carbonate and climatic records.

\section{Hole 558A Record}

Site 558 is located at approximately $37^{\circ} \mathrm{N}, 37^{\circ} \mathrm{W}$ on the west side of the Mid-Atlantic Ridge (Fig. 1). The water depth is $3750 \mathrm{~m}$, well above the observed lysocline and carbonate compensation depths for the late Pleistocene North Atlantic. This site is near the southern bound- 


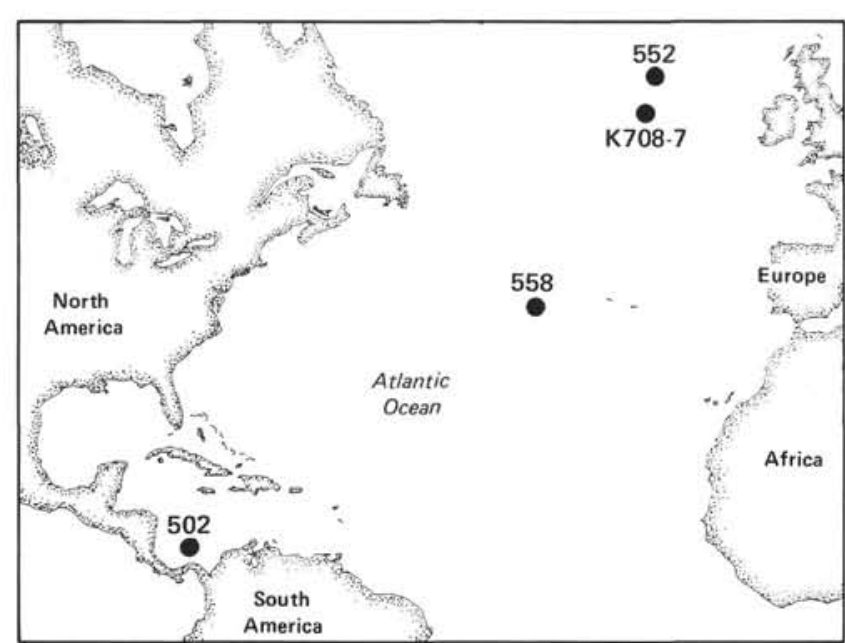

Figure 1. Map of the Atlantic Ocean, showing locations of Site K-7087 and of DSDP Sites 502, 552, and 558.

ary of major glacial to interglacial oceanographic fluctuations in the North Atlantic (CLIMAP, 1976; 1981).

Paleomagnetic data from Hole 558A show a complete upper Matuyama through Brunhes stratigraphy with welldefined reversals (M. J. Khan, pers. comm., 1983). The average accumulation rate for the upper 2-Ma section is $17 \mathrm{~m} / \mathrm{Ma}$. Accumulation rates vary between $11.3 \mathrm{~m} / \mathrm{Ma}$ for the Olduvai Subchron to $19.2 \mathrm{~m} / \mathrm{Ma}$ for the Brunhes chron (Table 1). The Jaramillo Subchron has an anomalously high accumulation rate of $48.6 \mathrm{~m} / \mathrm{Ma}$. Given these accumulation rates, we should be able to determine climatic variations identified in other deep-sea cores at Site 558.

Samples for carbonate and coarse fraction analyses were taken from the upper $34 \mathrm{~m}$ of Hole 558A. Sampling intervals generally were $10 \mathrm{~cm}$ resulting in an average sample spacing of $6 \mathrm{Ma}$.

\section{METHODS}

Coarse fraction determinations were made on all samples. A portion $\sim 0.5 \mathrm{~g}$ ) of sample was reserved for carbonate analysis; the remainder was dried at $50^{\circ} \mathrm{C}$, weighed, and then soaked overnight in water to disaggregate the sample. The samples were wet sieved through a $150 \mu \mathrm{m}$ sieve. Both coarse and fine fractions were retained; the coarse fractions were dried and weighed. Coarse fraction values are reported as the weight percent greater than $150 \mu \mathrm{m}$.

Wet sieving at $150 \mu \mathrm{m}$ reduces the time required for sample preparation. Most faunal, isotopic, and dissolution studies work with a size

Table 1. Accumulation rates calculated between magnetic reversals.

\begin{tabular}{lccc}
\hline \multicolumn{1}{c}{$\begin{array}{c}\text { Magnetic } \\
\text { boundary }\end{array}$} & $\begin{array}{c}\text { Depth } \\
(\mathrm{m})\end{array}$ & $\begin{array}{c}\text { Age } \\
(\mathrm{Ma})\end{array}$ & $\begin{array}{c}\text { Accumulation } \\
\text { rate }(\mathrm{m} / \mathrm{Ma})\end{array}$ \\
\hline Bruhnes/Matyuma & 14.0 & 0.73 & 19.2 \\
Top Jaramillo & 16.2 & 0.91 & 12.2 \\
Bottom Jaramillo & 19.6 & 0.98 & 48.6 \\
Top Olduvai & 29.02 & 1.66 & 13.9 \\
Bottom Olduvai & 31.5 & 1.88 & 11.3 \\
\hline
\end{tabular}

Note: The first column gives the lower boundary on the interval for the calculated accumulation rates. The magnetic reversals are from $\mathrm{M}$. J. Khan (pers. comm., 1983). fraction larger than $150 \mu \mathrm{m}$. For studies with large numbers of samples, the time saved can be significant.

Calcium carbonate analyses were made at Brown University using a differential-gasometric system similar in design to the vacuum-gasometric system described by Jones and Kaiteris (1983). In contrast to their system, the Brown system does not reference the resultant gas pressure after reaction to vacuum. The system measures the pressure difference between the carbonate bomb and the atmosphere.

The analytical system consists of two major components: (1) the sample chamber (carbonate bomb) and (2) the pressure manifold. The sample chamber (Jones and Kaiteris, 1983, fig. 1), is a two-arm glass reaction vessel with a quick connector and a valve for releasing the $\mathrm{CO}_{2}$ gas after reaction. The pressure manifold is composed of a quick connector, pressure gage, and relief valve.

Operation of the system can be summarized in four steps:

1. Raw samples $\left(1 / 2\right.$ to $\left.1 \mathrm{~cm}_{3}\right)$ are placed in an oven until dry. The sample is ground to a fine powder in a morter and redried.

2. A weighed amount of the sample $(0.1$ to $0.2 \mathrm{~g})$ is placed in the bottom of the reaction chamber; $3 \mathrm{ml}$ of $42 \%$ phosphoric acid is placed in the side arm.

3. After all samples are ready, the reaction vessel valves are closed and the acid is tipped onto the sample. The sample is agitated for $30 \mathrm{~s}$ or until the reaction stops.

4. Thirty minutes after the sample is reacted the pressure is measured by the connection of each reaction chamber to the pressure manifold. Temperatures are recorded at the time of pressure measurements. Atmospheric pressures are observed during the reaction and measurement phase for changes that may affect the result.

In practice, an operator can perform 30 carbonate analyses in a 2.0-hr. period, beginning with dry, powdered samples. Consistency between operators and reaction chambers is checked by running 3 to 5 standards with each set of samples. Carbonate standard is $100 \%$ analytical grade carbonate.

Precision of the differential-gasometric method is greater than the carbonate variations in most deep-sea sediment cores. The mean difference between random duplicate determinations was $0.8 \%$ for 61 samples from Hole 558A.

\section{RESULTS}

The upper $34 \mathrm{~m}$ of Hole $558 \mathrm{~A}$ record carbonate and coarse fraction variability spanning the last $2 \mathrm{Ma}$ (Fig. 2, end-of-chapter Appendix). The carbonate values range between 65 and $95 \%$ with a mean value of $83 \%$ ( $\sigma=$ $6.5 \%$ ). However, the pattern of carbonate variability is different for several sections of the record. Carbonate maxima and minima that correspond to isotopic Stages 3 through 12 are clearly defined in the upper $8 \mathrm{~m}$ of Hole 558A based on correlation to Holes 502 and 502B (Prell, 1982; Gardner, 1982) and Hole 552A (Shackleton and Hall, in press; Zimmerman et al., in press). During this interval, the carbonate record exhibits a characteristic Atlantic-type carbonate stratigraphy similar to carbonate records from Hole 552A and Core K708-7 (see Fig. 3). Core 558A-1 failed to recover the upper $0.5 \mathrm{~m}$ of sediment corresponding to the Holocene and last glacial maximum. Between 8 and $22 \mathrm{~m}$, the record is characterized by several broad carbonate maxima punctuated by two relatively sharp carbonate minima. Short-duration, low-amplitude variations are superimposed on the longperiod cycles. Below $22 \mathrm{~m}$, the relative duration and magnitude of major carbonate variations are similar to upper Pleistocene ( 0 to $8 \mathrm{~m}$ ) section.

The record of coarse fraction has a mean value of $10 \%(\sigma=3.8 \%)$; several patterns of variability occur within this record. The upper $6 \mathrm{~m}$ contains high-amplitude, short-duration variations and higher average values when compared to the entire record. A pronounced low-coarse-fraction event occurs between 6 and $10 \mathrm{~m}$ cor- 


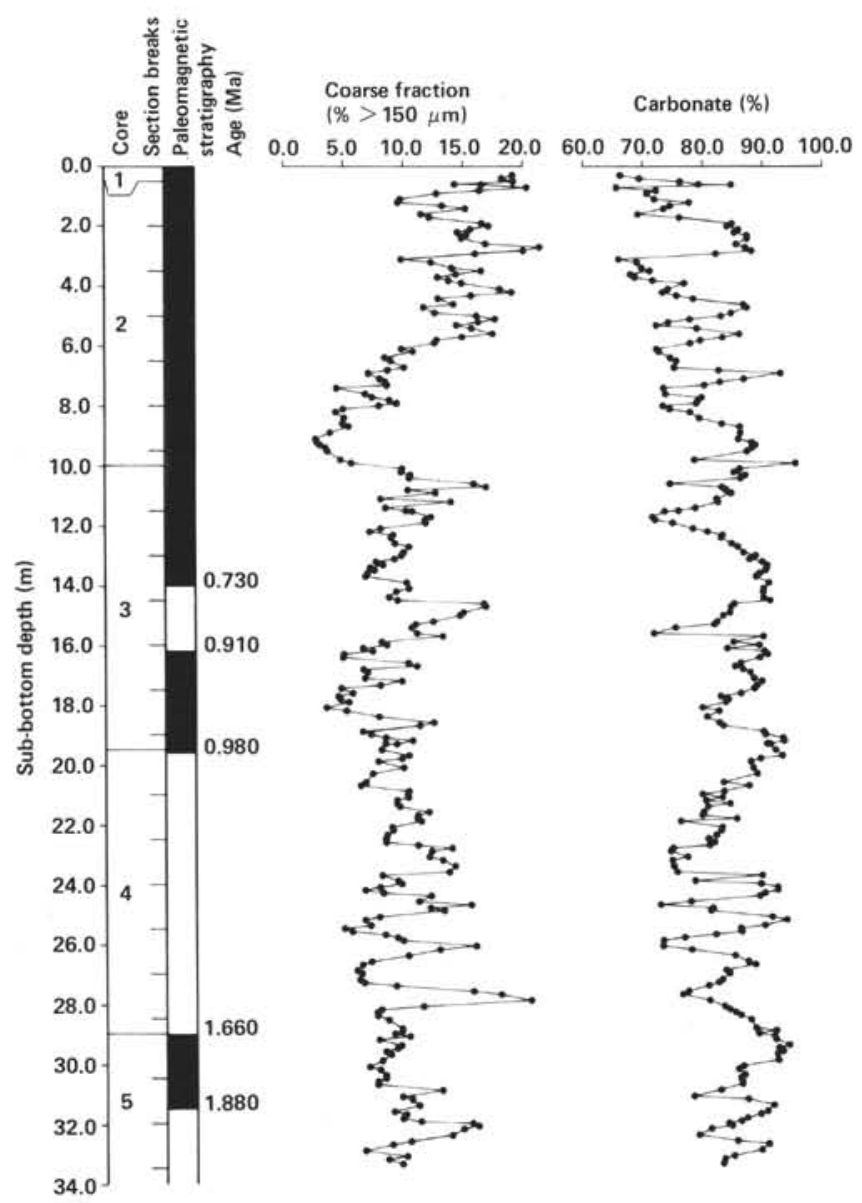

Figure 2. Coarse fraction and carbonate records from Hole 558A. Coarse fraction values are weight percent greater than $150 \mu \mathrm{m}$. Carbonate values are total weight percent carbonate. Magnetic time scale is from M. J. Khan (pers. comm., 1983). Magnetic ages are from Kent and Spariosu (1982). Hydraulic piston core numbers and section breaks are also shown. (See Table 1 for magnetic boundaries.)

responding approximately with Site 502 isotopic Stages 11 through 13 (Prell, 1982) (Fig. 3), that is not accompanied by a change in the carbonate record. Below $10 \mathrm{~m}$, coarse fraction values display a complex pattern of variability. In particular, the section between 22 and $28 \mathrm{~m}$ displays high-amplitude variations similar to, but out of phase with, the carbonate record.

The data from the upper $18 \mathrm{~m}$ of Hole $558 \mathrm{~A}$ show a poor correlation between the carbonate and coarse fraction records. Although the suggestion of an Atlantictype correlation is present during short intervals (e.g., 3 to $3.5 \mathrm{~m}$ ), the correlation over longer intervals is poor.

The lower Pleistocene section of Hole 558A (18 to $34 \mathrm{~m}$ ) displays a clear negative correlation between carbonate and coarse fraction values $(r=-0.5)$. This correlation is in contrast to the general positive correlation found in most upper Pleistocene North Atlantic sediments. The records of carbonate and coarse-fraction variability from Hole 558A may reflect the Pleistocene changes in the mode of climatic variability or may reflect changes in the response of the carbonate system to climatic fluctuations.

\section{DISCUSSION}

The carbonate record from Hole 558A is shown in Figure 3 with carbonate records from the Atlantic that have similar accumulation rates. Site 552 and Core K708-7 are North Atlantic carbonate records. The carbonate record from Site 502 (the Caribbean) is included for correlation with the $\delta^{18} \mathrm{O}$ stratigraphy.

Correlation lines in Figure 2 are drawn between magnetic reversals and several major carbonate events. In each Pleistocene record, carbonate events of similar amplitude are present in both the lower and upper Pleistocene sections. In the upper Pleistocene (upper $14 \mathrm{~m}$ of Hole 558A), the general structure, as shown by the correlation lines, is similar. Detailed correlations between the North Atlantic carbonate records show higher amplitude and variance in Hole 552A and Core K708-7 records when compared to Hole 558A. The lower Pleistocene carbonate record from Hole 552 also has higher amplitude and variance. Sites 552 and K708-7 are approximately $20^{\circ}$ north of Site 558 within a region influenced by fluctuations of the polar front (McIntyre et al., 1972; Ruddiman and McIntyre, 1976) and have a significant component of noncarbonate, ice rafted material resulting in an increased amplitude of the carbonate curve (Zimmerman et al., in press; Ruddiman and McIntyre, 1976). Site 558 is south of the maximum southern extent of the polar front during the last glacial maximum (CLIMAP, 1976, 1981; McIntyre et al., 1976) and thus less influenced by ice rafted material. Site 558 is also separated from major terrigenous sources by the Mid-Atlantic Ridge and the North American Basin. The accumulation rate for the lower Pleistocene of Hole 558A is lower than for the upper Pleistocene. The accumulation rate change in Hole 558A makes correlation to Holes 502B and 552A difficult; therefore, no carbonate correlation lines are drawn for the early Pleistocene.

The Pleistocene carbonate system presents a complex pattern of variability in Atlantic sediments. At Site 558, several modes of variability are present in both the carbonate and coarse fraction records. Whereas the entire lower Pleistocene does not have a single clear correlation, a significant interval (18 to $34 \mathrm{~m}$ ) has an inverse correlation. Several factors may contribute individually to the change in correlation between carbonate and coarse fraction, such as sediment winnowing, carbonate dissolution and production, and noncarbonate dilution. Increased winnowing during low carbonate events can remove fine fraction material increasing the coarse fraction values and may account for the decreased accumulation rate in the lower Pleistocene. Increased dissolution could lead to lower carbonate values with a higher coarse fraction only if the effects of dissolution are more pronounced on the fine fraction component. Productivity changes and the resulting changes in dissolution could effectively increase the carbonate content, but also would increase carbonate dissolution. At periods of high carbonate dissolution, fragmentation of foraminiferal tests, which form nearly all the coarse fraction, would reduce the coarse fraction values. Thus, the carbonate and coarse fraction variations would be inversely related. Increased 


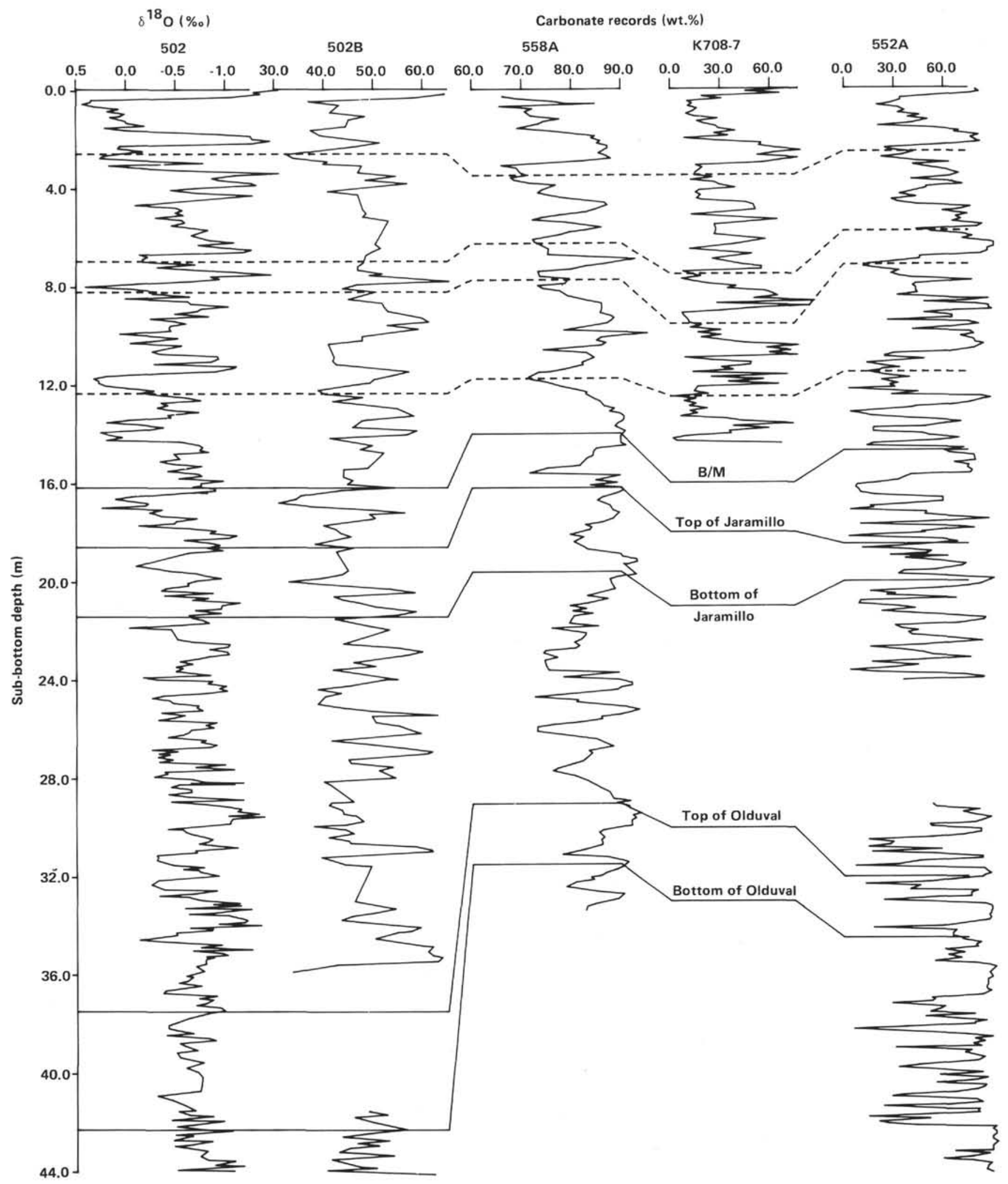

Figure 3. Correlation between $\delta^{18} \mathrm{O}$ and carbonate records. Oxygen isotopic data (in \%o versus PDB standard) are from Holes 502 and 502B (Prell, 1982 plus additional data). Carbonate record from Caribbean Hole 502B is from Gardner (1982); piston core K-7087 record is a fine-fraction carbonate record from the North Atlantic (Ruddiman and McIntyre, 1976); North Atlantic Hole 552A carbonate data are from Zimmerman et al. (in press). Correlations are shown for magnetic (solid lines) and carbonate (dashed lines) events. 
noncarbonate sedimentation could reduce the carbonate content, but should also reduce coarse fraction values (most of the noncarbonate material is in the fine fraction [Ruddiman and McIntyre, 1976]). Individually, these factors may contribute to the temporal variations in the carbonate system; however, the interrelationships between these factors must also be considered.

\section{CONCLUSIONS}

Examination of the carbonate and coarse fraction records from Site 558 and the correlation to other carbonate records reveals that:

1. Hole 558A contains records of carbonate and coarse fraction variations for the entire Pleistocene. Accumulation rates, however, may vary during the Pleistocene.

2. Carbonate and coarse fraction records display several modes of variability within the Pleistocene section. Among these modes are lower and upper Pleistocene sections containing high-amplitude variations.

3 . The correlation between carbonate and coarse fraction records varies from low values in most of the upper Pleistocene ( 0 to $18 \mathrm{~m}$ ) to a maximum of -0.5 for the lower Pleistocene (below $18 \mathrm{~m}$ ). The lower Pleistocene correlation is the opposite of the upper Pleistocene correlation observed in other North Atlantic and Caribbean records.

4. Correlation between Atlantic carbonate records shows that the carbonate variability is higher in northern sites (Site 552 and K708-7) where ice-rafted material is an important noncarbonate component.

From these observations we infer that the North Atlantic has had several modes of sedimentation and preservation of carbonate material at Site 558 and that the response of the carbonate system to different modes is not the same for each component.

\section{ACKNOWLEDGMENTS}

I thank W. L. Prell and J. Imbrie for assistance during the preparation of this manuscript and B. Bellis for assistance in performing the carbonate determinations. This study was supported by National Science Foundation grant ATM-8018897 (SPECMAP).

\section{REFERENCES}

Arrhenius, G., 1952. Sediment cores from the East Pacific. Fasc. I, Rep. Swed. Deep-Sea Exped., 5:6-227.

Berger, W. H., 1976. Biogenous deep sea sediments: production, preservation, and interpretation. In Riley, J. P., and Chester, R. (Eds.), Chemical Oceanography, (Vol. 5, 2nd ed.): London (Academic Press), pp. 265-388.

1982. Deep-sea stratigraphy: Cenozoic steps and the search for chemo-climatic feedback. In Einsele, G., and Seilacher, A. (Eds.), Cyclic and Event Stratification: Berlin (Springer), pp. 121-157.

Broecker, W. S., 1971. Calcite accumulation rates and glacial to interglacial changes in oceanic mixing. In Turekian, K. K. (Ed.), The Late Cenozoic Glacial Ages: New Haven (Yale), pp. 239-265.

Broecker, W. S., and Peng, T.-H., 1982. Tracers in the Sea: Palisades (Lamont-Doherty Geological Observatory).
CLIMAP, 1976. The surface of the ice-age Earth. Sciences, 191: $1131-1137$

1981. Seasonal reconstructions of the Earth's surface at the last glacial maximum. In McIntyre A., and Cline, R. (Eds.), Map and Chart Series: Boulder, Colorado (Geol. Soc. Am.), MC-36.

Emiliani, C., 1955. Pleistocene temperatures. J. Geol., 63:538-578.

Gardner, J. V., 1982. High-resolution carbonate and Quaternary organic-carbon stratigraphies for the late Neogene and Quaternary from the western Caribbean and eastern equatorial Pacific. In Prell, W. L., Gardner, J. V., et al., Init. Repts. DSDP, 68: Washington (U.S. Govt. Printing Office), 347-364.

Jones, G. A., and Kaiteris, P., 1983. A vacuum-gasometric technique for rapid and precise analysis of calcium carbonate in sediments and soils. J. Sediment. Petrol., 53:655-660.

Kent, D. V., Spariosu, D. J., 1982. Magnetostratigraphy of Caribbean Site 502 hydraulic piston cores. In Prell, W. A., Gardner, J. V., et al., Init. Repts. DSDP, 68: Washington (U.S. Govt. Printing Office), 419-433.

McIntyre, A., Kipp, N. G., Bé, A. W. H., Crowley, T., Kellogg, T., Gardner, J. V., Prell, W. L., and Ruddiman, W. F., 1976. Glacial North Atlantic 18,000 years ago: a CLIMAP reconstruction. In Cline, R. M., and Hays, J. D. (Eds.), Investigation of the Late Quaternary Paleoceanography and Paleoclimatology: Boulder, Colorado (Geol. Soc. Am.), Mem. 145:43-76.

McIntyre, A., Ruddiman, W. F., and Jantzen, R., 1972. Southward penetration of the North Atlantic Polar Front: faunal and floral evidence of large-scale surface water mass movement over the last 225,000 years. Deep-Sea Res., 19:61-77.

Phelger, F. B., Parker, F. L., and Peirson, J. F., 1953. North Atlantic foraminifera. Rept. Swed. Deep-Sea Exped. 1947-1948, 7.

Prell, W. L., 1982. Oxygen and carbon isotope stratigraphy for the Quaternary of Hole 502B: evidence for two modes of isotopic variability. In Prell, W. L., Gardner, J. V., et al., Init. Repts. DSDP, 68: Washington (U.S. Govt. Printing Office), 455-464.

1978. Upper Quaternary sediments of the Columbia Basin: spacial and stratigraphic variations. Geol. Soc. Am. Bull., 89: 1241-1255.

Ruddiman, W. F., 1971. Pleistocene sedimentation in the Equatorial Atlantic: stratigraphy and faunal paleoclimatology. Geol. Soc. Am. Bull., 82:283-302.

Ruddiman, W. F., and McIntyre, A., 1976. Northwest Atlantic paleoclimatic changes over the past 600,000 years. In Cline, R. M., and Hays, J. D. (Eds.), Investigation of the Late Quaternary Paleoceanography and Paleoclimatology: Boulder, Colorado (Geol. Soc. Am.), Mem. 145:3-41.

Shackleton, N. J., 1967. Oxygen isotopes analyses and Pleistocene temperature re-assessed. Nature, 215:15-17.

Shackleton, N. J., and Hall, M. A., in press. Oxygen and carbon isotope stratigraphy of DSDP Site 552A: Plio-Pleistocene glacial history. In Roberts, D. G., Schnitker, D., et al., in press. Init. Repts. DSDP, 81: Washington (U.S. Govt. Printing Office).

Shackleton, N. J., and Opdyke, N. D., 1976. Oxygen-isotope and paleomagnetic stratigraphy of Pacific core V28-239 late Pliocene to latest Pleistocene. In Cline, R. M., and Hays, J. D. (Eds.), Investigation of the Late Quaternary Paleoceanography and Paleoclimatology: Boulder, Colorado (Geol. Soc. Am.), Mem. 145:449-464.

Volat, J.-L., Pastouret, L., and Vernaud-Graggini, C., 1980. Dissolution and carbonate fluctuations in Pleistocene deep-sea cores: a review. Mar. Geol., 34:1-28.

Zimmerman, H. B., Shackleton, N. J., Backman, J., Kent, D. V., Baldauf, J. G., Kaltenback, A. J., and Morton, A. C., in press. History of Plio-Pleistocene climate in the northeastern Atlantic, Deep Sea Drilling Project Hole 552A. In Roberts, D. G., Schnitker, D., et al., Init. Repts. DSDP, 81: Washington (U.S. Govt. Printing Office).

Date of Initial Receipt: 8 November 1983

Date of Acceptance: 10 July 1984 
APPENDIX

Sample Identification, Depth, Coarse Fraction, and Carbonate Values for Hole 558A

\begin{tabular}{|c|c|c|c|}
\hline $\begin{array}{l}\text { Core-Section } \\
\text { (interval in } \mathrm{cm} \text { ) }\end{array}$ & $\begin{array}{l}\text { Sub-bottom } \\
\text { depth } \\
\text { (m) }\end{array}$ & $\begin{array}{c}\text { Carbonate } \\
\text { (wt. \%) }\end{array}$ & $\begin{array}{l}\text { Coarse } \\
\text { fraction } \\
(w t . \%)\end{array}$ \\
\hline $1-1,29-31$ & 0.30 & 66.27 & 19.12 \\
\hline $1-1,39-41$ & 0.40 & 69.50 & 18.21 \\
\hline $1-1,49-51$ & 0.50 & 76.25 & 19.19 \\
\hline $1-1,58-60$ & 0.59 & 79.32 & 14.29 \\
\hline $2-1,9-11$ & 0.60 & 84.81 & 16.55 \\
\hline $2-1,19-21$ & 0.70 & 65.63 & 20.30 \\
\hline $2-1,29-31$ & 0.08 & 72.30 & 16.39 \\
\hline $2-1,39-41$ & 0.90 & 70.76 & 12.79 \\
\hline $2-1,58-60$ & 1.09 & 71.98 & 9.76 \\
\hline $2-1,69-71$ & 1.20 & 77.74 & 9.56 \\
\hline $2-1,80-82$ & 1.31 & 74.54 & 13.25 \\
\hline $2-1,90-92$ & 1.41 & 73.52 & 15.19 \\
\hline $2-1,108-110$ & 1.59 & 69.20 & 11.48 \\
\hline $2-1,119-121$ & 1.70 & 76.15 & 12.17 \\
\hline $2-1,139-140$ & 1.90 & 84.90 & 16.56 \\
\hline $2-1,148-150$ & 1.99 & 84.11 & 17.12 \\
\hline $2-2,9-11$ & 2.10 & 85.98 & 15.62 \\
\hline $2-2,19-21$ & 2.20 & 85.27 & 14.52 \\
\hline $2-2,29-31$ & 2.30 & 87.40 & 15.28 \\
\hline $2-2,39-41$ & 2.40 & 87.43 & 14.88 \\
\hline $2-2,58-60$ & 2.59 & 85.59 & 16.87 \\
\hline $2-2,69-71$ & 2.70 & 87.12 & 21.37 \\
\hline $2-2,80-82$ & 2.81 & 88.17 & 20.02 \\
\hline $2-2,90-92$ & 2.91 & 82.14 & 16.02 \\
\hline $2-2,109-111$ & 3.10 & 65.96 & 9.80 \\
\hline $2-2,119-121$ & 3.20 & 69.01 & 12.32 \\
\hline $2-2,138-140$ & 3.39 & 69.80 & 14.04 \\
\hline $2-2,148-150$ & 3.49 & 71.11 & 16.50 \\
\hline $2-3,9-11$ & 3.60 & 67.92 & 14.39 \\
\hline $2-3,19-21$ & 3.70 & 68.63 & 12.87 \\
\hline $2-3,30-32$ & 3.81 & 71.63 & 13.77 \\
\hline $2-3,40-42$ & 3.90 & 76.92 & 14.88 \\
\hline $2-3,58-60$ & 4.09 & 74.16 & 18.05 \\
\hline $2-3,69-71$ & 4.20 & 73.25 & 19.04 \\
\hline $2-3,80-82$ & 4.31 & 75.60 & 15.68 \\
\hline $2-3,90-92$ & 4.41 & 78.39 & 12.87 \\
\hline $2-3,109-111$ & 4.60 & 86.80 & 14.19 \\
\hline $2-3,119-121$ & 4.70 & 87.38 & 11.65 \\
\hline $2-3,138-140$ & 4.89 & 84.74 & 12.60 \\
\hline $2-3,148-150$ & 4.99 & 83.00 & 16.11 \\
\hline $2-4,9-11$ & 5.10 & 77.78 & 17.64 \\
\hline $2-4,19-21$ & 5.20 & 74.21 & 16.27 \\
\hline $2-4,29-31$ & 5.30 & 72.17 & 14.41 \\
\hline $2-4,39-41$ & 5.40 & 78.94 & 15.70 \\
\hline $2-4,58-60$ & 5.59 & 86.11 & 17.45 \\
\hline $2-4,69-71$ & 5.70 & 83.24 & 14.90 \\
\hline $2-4,79-81$ & 5.80 & 79.54 & 12.77 \\
\hline $2-4,89-91$ & 5.90 & 77.86 & 12.57 \\
\hline $2-4,109-111$ & 6.10 & 72.25 & 9.80 \\
\hline $2-4,118-120$ & 6.19 & 72.60 & 10.77 \\
\hline $2-4,138-140$ & 6.39 & 74.52 & 8.42 \\
\hline $2-4,148-150$ & 6.49 & 75.50 & 8.92 \\
\hline $2-5,20-22$ & 6.71 & 75.18 & 10.03 \\
\hline $2-5,29-31$ & 6.80 & 82.62 & 8.65 \\
\hline $2-5,39-41$ & 6.90 & 92.93 & 7.03 \\
\hline $2-5,58-60$ & 7.09 & 86.85 & 8.00 \\
\hline $2-5,69-70$ & 7.19 & 82.82 & 8.43 \\
\hline $2-5,79-81$ & 7.30 & 80.17 & 8.57 \\
\hline $2-5,89-91$ & 7.40 & 73.37 & 4.38 \\
\hline $2-5,109-111$ & 7.60 & 73.74 & 6.80 \\
\hline $2-5,119-121$ & 7.70 & 79.73 & 7.34 \\
\hline $2-5,129-131$ & 7.80 & 79.12 & 8.77 \\
\hline $2-5,139-141$ & 7.90 & 78.83 & 9.40 \\
\hline $2-5,148-150$ & 7.99 & 73.27 & 7.91 \\
\hline $2-6,9-11$ & 8.10 & 74.43 & 4.92 \\
\hline $2-6,19-21$ & 8.20 & 77.80 & 4.32 \\
\hline $2-6,39-41$ & 8.40 & 79.33 & 5.01 \\
\hline $2-6,58-60$ & 8.59 & 83.13 & 4.89 \\
\hline $2-6,69-70$ & 8.69 & 86.16 & 5.38 \\
\hline $2-6,89-91$ & 8.90 & 86.26 & 3.81 \\
\hline $2-6,109-111$ & 9.10 & 85.90 & 2.60 \\
\hline $2-6,120-122$ & 9.21 & 88.13 & 2.72 \\
\hline $2-6,129-131$ & 9.30 & 88.75 & 2.97 \\
\hline $2-6,138-140$ & 9.39 & 88.19 & 3.40 \\
\hline
\end{tabular}

Appendix. (Continued).

\begin{tabular}{|c|c|c|c|}
\hline $\begin{array}{c}\text { Core-Section } \\
\text { (interval in } \mathrm{cm} \text { ) }\end{array}$ & $\begin{array}{l}\text { Sub-bottom } \\
\text { depth } \\
\text { (m) }\end{array}$ & $\begin{array}{c}\text { Carbonate } \\
\text { (wt.\%) }\end{array}$ & $\begin{array}{l}\text { Coarse } \\
\text { fraction } \\
\text { (wt.\%) }\end{array}$ \\
\hline $2-7,0-2$ & 9.51 & 87.32 & 3.59 \\
\hline $2-7,29-31$ & 9.80 & 78.56 & 4.71 \\
\hline $2, \mathrm{CC}(10-12)$ & 9.91 & 95.43 & 5.61 \\
\hline $3-1,9-11$ & 10.10 & 86.14 & 9.83 \\
\hline $3-1,19-21$ & 10.20 & 85.14 & 9.73 \\
\hline $3-1,29-31$ & 10.30 & 87.09 & 10.52 \\
\hline $3-1,39-41$ & 10.40 & 86.24 & 10.42 \\
\hline $3-1,58-60$ & 10.59 & 74.42 & 15.81 \\
\hline $3-1,69-71$ & 10.70 & 83.10 & 16.83 \\
\hline $3-1,79-81$ & 10.80 & 83.86 & 10.30 \\
\hline $3-1,89-91$ & 10.90 & 84.68 & 12.60 \\
\hline $3-1,109-11$ & 11.10 & 82.20 & 8.04 \\
\hline $3-1,119-121$ & 11.20 & 82.45 & 13.90 \\
\hline $3-1,138-140$ & 11.39 & 78.64 & 8.44 \\
\hline $3-1,148-150$ & 11.49 & 75.86 & 10.15 \\
\hline $3-2,0-2$ & 11.51 & 73.54 & 10.67 \\
\hline $3-2,19-21$ & 11.70 & 71.47 & 12.25 \\
\hline $3-2,29-31$ & 11.80 & 71.95 & 11.73 \\
\hline $3-2,39-41$ & 11.90 & 74.88 & 11.79 \\
\hline $3-2,58-60$ & 12.09 & 78.22 & 8.04 \\
\hline $3-2,69-71$ & 12.20 & 80.68 & 7.11 \\
\hline $3-2,80-82$ & 12.31 & 83.20 & 9.08 \\
\hline $3-2,89-91$ & 12.40 & 82.93 & 8.89 \\
\hline $3-2,109-111$ & 12.60 & 84.74 & 9.23 \\
\hline $3-2,119-121$ & 12.70 & 85.80 & 10.41 \\
\hline $3-2,138-140$ & 12.89 & 86.73 & 9.96 \\
\hline $3-2,148-150$ & 12.99 & 88.76 & 9.76 \\
\hline $3-3,10-12$ & 13.11 & 87.73 & 9.17 \\
\hline $3-3,19-21$ & 13.20 & 89.88 & 7.64 \\
\hline $3-3,30-32$ & 13.31 & 90.66 & 8.24 \\
\hline $3-3,39-41$ & 13.40 & 90.62 & 7.17 \\
\hline $3-3,48-50$ & 13.49 & 90.41 & 7.52 \\
\hline $3-3,58-60$ & 13.59 & 89.43 & 6.93 \\
\hline $3-3,69-71$ & 13.70 & 88.84 & 6.78 \\
\hline $3-3,89-91$ & 13.90 & 90.96 & 10.19 \\
\hline $3-3,109-111$ & 14.10 & 90.04 & 10.40 \\
\hline $3-3,119-121$ & 14.20 & 90.02 & 9.32 \\
\hline $3-3,138-140$ & 14.39 & 90.06 & 8.74 \\
\hline $3-3,148-150$ & 14.49 & 91.13 & 9.43 \\
\hline $3-4,9-11$ & 14.60 & 85.15 & 16.67 \\
\hline $3-4,19-21$ & 14.70 & 84.62 & 16.80 \\
\hline $3-4,39-41$ & 14.90 & 84.39 & 14.94 \\
\hline $3-4,49-51$ & 15.00 & 83.24 & 14.65 \\
\hline $3-4,69-71$ & 15.20 & 82.19 & 12.40 \\
\hline $3-4,78-80$ & 15.29 & 81.74 & 10.95 \\
\hline $3-4,89-91$ & 15.40 & 75.29 & 10.60 \\
\hline $3-4,109-111$ & 15.60 & 71.68 & 11.04 \\
\hline $3-4,119-121$ & 15.70 & 90.00 & 13.20 \\
\hline $3-4,138-140$ & 15.89 & 85.00 & 8.11 \\
\hline $3-4,148-150$ & 15.99 & 89.32 & 8.54 \\
\hline $3-5,9-11$ & 16.10 & 83.93 & 6.55 \\
\hline $3-5,19-21$ & 16.20 & 90.22 & 7.37 \\
\hline $3-5,29-31$ & 16.30 & 90.69 & 4.95 \\
\hline $3-5,39-41$ & 16.40 & 89.41 & 4.89 \\
\hline $3-5,58-60$ & 16.59 & 86.25 & 10.32 \\
\hline $3-5,69-71$ & 16.70 & 85.26 & 11.04 \\
\hline $3-5,79-81$ & 16.80 & 86.56 & 6.58 \\
\hline $3-5,89-91$ & 16.90 & 87.85 & 6.94 \\
\hline $3-5,109-111$ & 17.10 & 88.43 & 6.69 \\
\hline $3-5,119-121$ & 17.20 & 89.74 & 9.77 \\
\hline $3-5,133-135$ & 17.34 & 88.96 & 7.99 \\
\hline $3-5,143-145$ & 17.44 & 88.49 & 4.73 \\
\hline $3-6,9-11$ & 17.60 & 86.25 & 5.69 \\
\hline $3-6,19-21$ & 17.70 & 82.83 & 4.49 \\
\hline $3-6,29-31$ & 17.80 & 84.14 & 4.63 \\
\hline $3-6,39-41$ & 17.90 & 83.72 & 5.36 \\
\hline $3-6,58-60$ & 18.09 & 79.71 & 3.48 \\
\hline $3-6,69-71$ & 18.20 & 82.49 & 5.15 \\
\hline $3-6,89-91$ & 18.40 & 80.52 & 7.86 \\
\hline $3-6,109-111$ & 18.60 & 82.55 & 12.43 \\
\hline $3-6,119-121$ & 18.70 & 83.24 & 11.27 \\
\hline $3-6,138-140$ & 18.89 & 90.02 & 6.49 \\
\hline $3-6,148-150$ & 18.99 & 90.32 & 7.19 \\
\hline $3-7,9-11$ & 19.10 & 93.20 & 8.41 \\
\hline
\end{tabular}


Appendix. (Continued).

\begin{tabular}{|c|c|c|c|}
\hline $\begin{array}{l}\text { Core-Section } \\
\text { (interval in cm) }\end{array}$ & $\begin{array}{l}\text { Sub-bottom } \\
\text { depth } \\
\text { (m) }\end{array}$ & $\begin{array}{c}\text { Carbonate } \\
\text { (wt. \%) }\end{array}$ & $\begin{array}{c}\text { Coarse } \\
\text { fraction } \\
\text { (wt. \%) }\end{array}$ \\
\hline $3-7,19-21$ & 19.20 & 93.37 & 10.67 \\
\hline $3-7,30-32$ & 19.31 & 91.08 & 9.34 \\
\hline $3, C C(9-11)$ & 19.30 & 90.54 & 8.40 \\
\hline $4-1,0-2$ & 19.51 & 91.93 & 8.05 \\
\hline $4-1,19-21$ & 19.70 & 93.11 & 10.34 \\
\hline $4-1,29-31$ & 19.80 & 89.47 & 9.75 \\
\hline $4-1,39-41$ & 19.90 & 87.82 & 7.78 \\
\hline $4-1,59-61$ & 20.10 & 88.21 & 9.90 \\
\hline $4-1,79-81$ & 20.30 & 88.93 & 7.31 \\
\hline $4-1,108-110$ & 20.59 & 83.26 & 6.73 \\
\hline $4-1,119-121$ & 20.70 & 87.51 & 6.32 \\
\hline $4-1,138-140$ & 20.89 & 83.36 & 10.33 \\
\hline $4-1,148-150$ & 20.99 & 79.70 & 10.23 \\
\hline $4-2,9-11$ & 21.10 & 83.07 & 10.28 \\
\hline $4-2,19-21$ & 21.20 & 80.25 & 9.34 \\
\hline $4-2,29-31$ & 21.30 & 84.37 & 9.33 \\
\hline $4-2,39-41$ & 21.40 & 80.58 & 9.55 \\
\hline $4-2,58-60$ & 21.59 & 79.88 & 11.99 \\
\hline $4-2,69-71$ & 21.70 & 79.64 & 11.07 \\
\hline $4-2,80-82$ & 21.81 & 85.45 & 11.01 \\
\hline $4-2,89-91$ & 21.90 & 76.07 & 11.34 \\
\hline $4-2,109-111$ & 22.10 & 83.01 & 8.92 \\
\hline $4-2,119-121$ & 22.20 & 82.86 & 9.02 \\
\hline $4-2,135-137$ & 22.36 & 82.02 & 8.52 \\
\hline $4-2,147-149$ & 22.48 & 80.60 & 8.37 \\
\hline $4-3,9-11$ & 22.60 & 81.66 & 8.41 \\
\hline $4-3,19-21$ & 22.70 & 80.84 & 11.06 \\
\hline $4-3,29-31$ & 22.80 & 74.76 & 13.93 \\
\hline $4-3,39-41$ & 22.90 & 74.35 & 12.20 \\
\hline $4-3,58-60$ & 23.09 & 77.17 & 12.01 \\
\hline $4-3,69-71$ & 23.20 & 74.63 & 13.12 \\
\hline $4-3,89-91$ & 23.40 & 74.84 & 14.16 \\
\hline $4-3,109-111$ & 23.60 & 75.40 & 13.69 \\
\hline $4-3,119-121$ & 23.70 & 89.64 & 8.07 \\
\hline $4-3,138-140$ & 23.89 & 78.40 & 9.41 \\
\hline $4-3,148-150$ & 23.99 & 89.46 & 9.71 \\
\hline $4-4,9-11$ & 24.10 & 92.26 & 7.88 \\
\hline $4-4,19-21$ & 24.20 & 92.27 & 6.64 \\
\hline $4-4,29-31$ & 24.30 & 90.10 & 8.17 \\
\hline $4-4,39-41$ & 24.40 & 89.25 & 12.14 \\
\hline $4-4,58-60$ & 24.59 & 77.68 & 11.11 \\
\hline $4-4,69-71$ & 24.70 & 72.63 & 15.49 \\
\hline $4-4,80-82$ & 24.81 & 81.35 & 12.08 \\
\hline $4-4,89-91$ & 24.90 & 81.01 & 13.22 \\
\hline $4-4,109-111$ & 25.10 & 91.32 & 7.84 \\
\hline $4-4,119-121$ & 25.20 & 93.74 & 6.63 \\
\hline $4-4,138-140$ & 25.39 & 90.13 & 7.09 \\
\hline $4-4,148-150$ & 25.49 & 86.05 & 4.90 \\
\hline $4-5,9-11$ & 25.60 & 86.22 & 5.54 \\
\hline $4-5,19-21$ & 25.70 & 81.87 & 8.30 \\
\hline $4-5,29-31$ & 25.80 & 76.63 & 9.32 \\
\hline $4-5,39-41$ & 25.90 & 73.14 & 9.80 \\
\hline $4-5,58-60$ & 26.09 & 73.02 & 15.88 \\
\hline $4-5,69-71$ & 26.20 & 77.80 & 12.84 \\
\hline $4-5,89-91$ & 26.40 & 85.09 & 10.23 \\
\hline
\end{tabular}

Appendix. (Continued).

\begin{tabular}{|c|c|c|c|}
\hline $\begin{array}{l}\text { Core-Section } \\
\text { (interval in cm) }\end{array}$ & $\begin{array}{l}\text { Sub-bottom } \\
\text { depth } \\
\text { (m) }\end{array}$ & $\begin{array}{c}\text { Carbonate } \\
\text { (wt. \%) }\end{array}$ & $\begin{array}{l}\text { Coarse } \\
\text { fraction } \\
\text { (wt. \%) }\end{array}$ \\
\hline $4-5,109-111$ & 26.60 & 87.32 & 7.15 \\
\hline $4-5,119-121$ & 26.70 & 88.51 & 6.40 \\
\hline $4-5,138-140$ & 26.89 & 83.54 & 5.95 \\
\hline $4-5,148-150$ & 26.99 & 84.22 & 6.36 \\
\hline $4-6,19-21$ & 27.20 & 82.95 & 6.18 \\
\hline $4-6,29-31$ & 27.30 & 82.31 & 6.55 \\
\hline $4-6,39-41$ & 27.40 & 80.63 & 9.21 \\
\hline $4-6,58-60$ & 27.59 & 77.26 & 15.66 \\
\hline $4-6,69-71$ & 27.70 & 76.24 & 17.97 \\
\hline $4-6,89-91$ & 27.90 & 80.76 & 20.48 \\
\hline $4-6,109-111$ & 28.10 & 83.27 & 11.48 \\
\hline $4-6,119-121$ & 28.20 & 84.16 & 7.96 \\
\hline $4-6,129-131$ & 28.30 & 85.15 & 7.62 \\
\hline $4-6,139-141$ & 28.40 & 86.04 & 7.64 \\
\hline $4-7,4-6$ & 28.55 & 87.72 & 8.55 \\
\hline $4, C C(2-4)$ & 28.83 & 88.55 & 9.68 \\
\hline $4, \mathrm{CC}(10-12)$ & 28.91 & 91.94 & 9.68 \\
\hline $4, C C(20-22)$ & 29.01 & 89.02 & 9.05 \\
\hline $5-1,9-11$ & 29.10 & 91.66 & 10.32 \\
\hline $5-1,19-21$ & 29.20 & 91.84 & 7.77 \\
\hline $5-1,39-41$ & 29.40 & 94.08 & 9.59 \\
\hline $5-1,48-50$ & 29.49 & 92.41 & 9.27 \\
\hline $5-1,59-61$ & 29.60 & 93.05 & 8.33 \\
\hline $5-1,69-71$ & 29.70 & 91.11 & 8.73 \\
\hline $5-1,89-91$ & 29.90 & 92.26 & 8.00 \\
\hline $5-1,109-111$ & 30.10 & 86.45 & 6.94 \\
\hline $5-1,119-121$ & 30.20 & 85.59 & 7.83 \\
\hline $5-1,138-140$ & 30.39 & 86.65 & 8.30 \\
\hline $5-1,148-150$ & 30.49 & 86.00 & 8.30 \\
\hline $5-2,9-11$ & 30.60 & 86.21 & 7.68 \\
\hline $5-2,19-21$ & 30.70 & 86.26 & 7.65 \\
\hline $5-2,39-41$ & 30.90 & 82.55 & 13.02 \\
\hline $5-2,59-61$ & 31.10 & 78.11 & 9.68 \\
\hline $5-2,69-71$ & 31.20 & 87.19 & 10.50 \\
\hline $5-2,89-91$ & 31.40 & 91.45 & 11.06 \\
\hline $5-2,109-111$ & 31.60 & 90.39 & 8.97 \\
\hline $5-2,119-121$ & 31.70 & 89.27 & 9.98 \\
\hline $5-2,133-135$ & 31.84 & 87.05 & 9.72 \\
\hline $5-2,143-145$ & 31.94 & 85.99 & 11.22 \\
\hline $5-3,0-2$ & 32.01 & 83.89 & 15.53 \\
\hline $5-3,9-11$ & 32.10 & 84.46 & 16.04 \\
\hline $5-3,19-21$ & 32.20 & 80.91 & 14.78 \\
\hline $5-3,39-41$ & 32.40 & 78.89 & 13.82 \\
\hline $5-3,59-61$ & 32.60 & 85.33 & 10.36 \\
\hline $5-3,69-71$ & 32.70 & 90.59 & 8.86 \\
\hline $5-3,89-91$ & 32.90 & 89.41 & 6.60 \\
\hline $5-3,109-111$ & 33.10 & 84.76 & 10.06 \\
\hline $5-3,119-121$ & 33.20 & 83.14 & 8.52 \\
\hline $5-3,135-137$ & 33.36 & 82.89 & 9.69 \\
\hline
\end{tabular}

Note: Sub-bottom depths are expressed as depth to the middle of the sample interval as measured from the top of the section. Replicate carbon analyses were averaged. Coarse fraction values are wt. $\%$ greater than $150 \mu \mathrm{m}$. 